\title{
A NOVEL FULLY FAST RECOVERY EMG AMPLIFIER FOR THE CONTROL OF NEURAL PROSTHESIS
}

\author{
Vojin Ilić, Nikola Jorgovanović, Aco Antić, Slobodan Morača, Nikolae Ungureanu
}

Original scientific article

This paper presents a novel EMG (electromyography) fast recovery amplifier, which can be used as a neural prosthesis control interface. The basis of the proposed circuit is standard three op-amp amplifier with integrator in the negative feed-back loop of the differential amplifier. The Standard three op-amp instrumentation amplifier has been modified by introducing analog delay line between the first stage (differential input - differential output amplifier) and the second stage (differential amplifier). The main purpose of the analog delay line is to delay EMG signal and the stimulus artifact between the first and the second stage. It is shown that by introducing a delay line in the standard three op-amp instrumentation amplifier, stimulus artifact can be detected before it appears at the output of the amplifier. Thus the control circuits of the amplifier have enough time to disable the integrator in the differential amplifier, and prevent charge accumulation in the integrators capacitor. It is also shown that this configuration of the EMG amplifier has ultrafast recovery time, so it can be used as a control interface of the neural prosthesis.

Keywords: analog delay line; EMG Amplifier; instrumentation amplifier; neural prosthesis

Novo u potpunosti brzo oporavljivo EMG pojačalo za kontrolu neuronskih proteza

Izvorni znanstveni članak Ovaj članak predstavlja novo EMG (elektromiografsko) brzo oporavljivo pojačalo, koje se može koristiti kao sučelje za kontrolu neuronskih proteza. Osnova predloženog električnog kruga je standardno instrumentacijsko pojačalo implementirano pomoću tri operacijska pojačala s integratorom u negativnoj povratnoj petlji diferencijalnog pojačala. Standardno instrumentacijsko pojačalo s tri operacijska pojačala je modificirano uvođenjem analogne linije za kašnjenje između prvog stupnja (diferencijalni ulaz - diferencijalno izlazno pojačalo) i drugog stupnja (diferencijalno pojačalo). Glavna svrha analogne linije za kašnjenje je kašnjenje EMG signala i poticaj artefakta između prvog i drugog stupnja. Uvođenjem linije za kašnjenje u standardnom instrumentacijskom pojačalu s tri operacijska pojačala, pokazano je da se poticaj artefakta može otkriti prije nego što se pojavi na izlazu iz pojačala. Na taj način kontrolni sklopovi pojačala imaju dovoljno vremena da onemoguće integrator u diferencijalnom pojačalu, i spriječe nakupljanje naboja u kondenzatoru integratora. Također je pokazano da ova konfiguracija EMG pojačala ima ultra brzo vrijeme oporavka, tako da se može koristiti kao sučelje za kontrolu neuronskih proteza.

Ključne riječi: analogna linija za kašnjenje; EMG pojačalo; instrumentacijsko pojačalo; neuronske proteze

\section{Introduction}

Neural prostheses are devices that could restore motor functions to people with spinal cord injury disease (SCI). They contribute to execution of effective movements. Recordings of the electromyographic (EMG) signals during electrical stimulation are often used as control signal for neural prosthesis $[1,2]$. When surface electrodes are used for recording and stimulation, they are often located very close to each other [3]. Therefore, each stimulation pulse causes artefact in the EMG signal [4] and increases DC potentials on the EMG electrodes [5]. Amplitude and frequency range of the EMG signals are a few $\mathrm{mV}$ and about $10 \mathrm{~Hz}$ to $1000 \mathrm{~Hz}$, respectively [5]. Amplitudes of the stimulation pulses are several orders in magnitude greater than the EMG signal amplitude [6].

Generally, EMG recording amplifiers are designed as three op-amp instrumentation amplifiers with high-pass filter to remove DC electrode offset potential [7, 8, 9]. When recording EMG signal during stimulation with these amplifiers, the stimulation artefact saturates the amplifier. Saturated amplifier has no ability of recording the EMG signal as long as it stays in the saturation. Duration on the saturation depends of the used op-amps and high-pass filter cut off frequency [6].

Many authors have discussed this problem in literature. Freeman proposed a gated sample and hold amplifier that switches to the hold mode during the stimulation artefact. Babb et al. [11] proposed a modified version of the Freeman circuit for the recording of brain evoked potentials. In [12], authors propose amplifier with integrator in the feedback loop for achieving high-pass filter characteristics. Amplifier has the circuit that detects near saturation point of the amplifier and in fixed period of time disconnects integrator from the circuit to keep the amplifier at baseline. Minzly el al. [13] proposes stimulus suppressor that automatically disconnects the amplifier from the electrodes during stimulation. Proposed circuit has the ability to detect stimulation pulse and to automatically blank the amplifiers input. Time of the blank period is set by the one monostable multivibrator (MM). Recording interval of the amplifier is also set by another MM. Nikolic et al. [14] proposed transformer coupled instrumentation amplifier for boosting $\mu \mathrm{V}$ signals with blanking input for reduction of the stimulus artefact. Fast recovery amplifier was discussed [15]. The author showed that artefact suppression is possible by using fast recovery instrumentation amplifiers and a nonlinear feedback loop for automatic compensation of changes in DC-offset. Stimulus resistant neural recording amplifier was proposed in [16]. Control of the amplifier is performed by a stimulator. During stimulation pulse, stimulator moves the high-pass cut off frequency of the amplifier from $10 \mathrm{~Hz}$ to $10 \mathrm{kHz}$. With such a high loopbandwidth, the amplifier system attempts to track out the stimulus artefact, in real-time, as it is presented to the inputs. In [17] authors show how to use same electrode for recording and stimulation. The proposed system is synchronized with an electronic stimulator. The 
Electronic stimulator activates blanking switches before stimulation pulse, and deactivates it after pulse.

In this work, we propose a novel configuration of the EMG amplifier that has the ability of recording the EMG signal during electrical stimulation. This configuration is based on the modification of the standard three op-amp instrumentation amplifier with active DC suppression, by introducing analog delay line and stimulation artefact detection circuit. Analog delay line is placed between the first and the second stage of the instrumentation amplifier. Stimulation artefact detection circuit is placed at the output of the first stage. By introducing analog delay line in the standard three op-amp instrumentation amplifier, input signal can be delayed, so the stimulation artefact detection circuit can detect stimulation before it is present at the amplifiers output. The active DC suppression is turned off just before the stimulation artefact appears, and turned back on $1 \mathrm{~ms}$ after stimulation artefact. Therefore, the new design can be used as control interface for any neural prosthesis.

\section{The novelty of the new fast recovery EMG amplifier}

For optimal stimulus artefact reduction, the EMG amplifier should be turned-off before stimulation pulse and turned-on after stimulation pulse [18].

Simplified schematic of the developed amplifier is shown in Figure 1. The circuit is designed to operate at dual $( \pm 5 \mathrm{~V})$ power supply. According to design requirements based on [15], differential gain of the amplifier is set to $60 \mathrm{~dB}$ in the pass band from $10 \mathrm{~Hz}$ to $1000 \mathrm{~Hz}$. The amplifier is designed for typical input signal which consists of EMG and stimulation artefact with the following characteristics [15]:

- Myoelectric signals: Less than $0,5 \mathrm{mV}$, frequency range: $10 \mathrm{~Hz} \div 1 \mathrm{kHz}$;

- Stimulation artefacts: Less than $\pm 5 \mathrm{~V}$;

- Electrode offset changing within range of $\pm 100 \mathrm{mV}$ and amplifier recovery time less than $50 \mathrm{~ms}$;

- Blanking interval of the amplifier: at least $10 \mu \mathrm{s}$ before stimulation pulse, $1 \mathrm{~ms}$ after stimulation pulse.

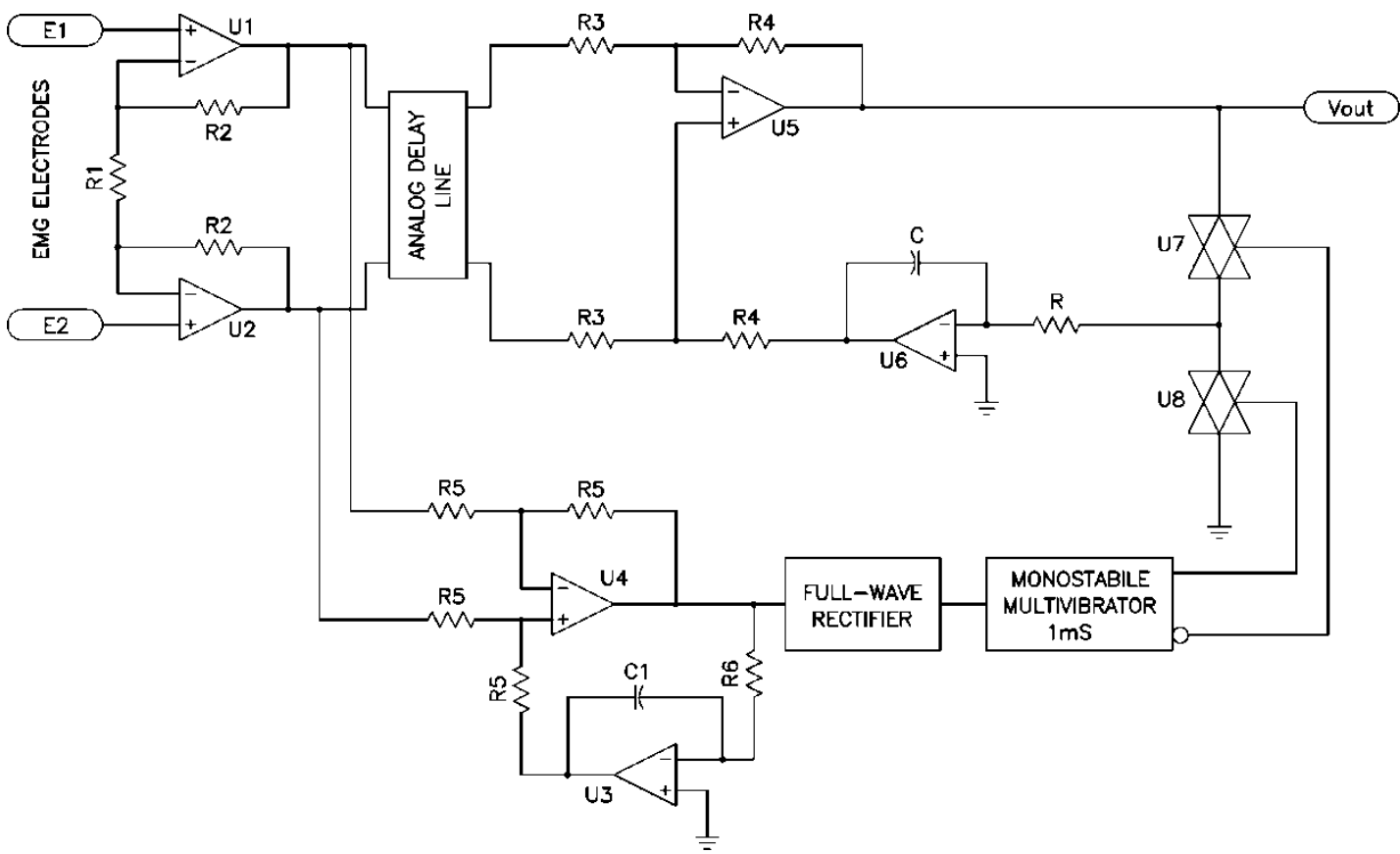

Figure 1Simplified schematic of the proposed circuit

The proposed circuit can be broken down into several stages: input stage, analog delay line, circuit for detection of the stimulation artefact and the output stage. The Input stage is implemented as amplifier with differential input and differential output: $\mathrm{U}_{1}, \mathrm{U}_{2}, \mathrm{R}_{1}, \mathrm{R}_{2}$. This is true DC amplifier and has no influence on the stimulation artefact. Transfer function of the first stage is given by:

$A_{\mathrm{DI}}(s)=1+\frac{2 R_{2}}{R_{1}}$

Amplification of the first stage is set to $20 \mathrm{~dB}$ to prevent saturation caused by electrode offset.

To achieve stimulus artefact detection, we made signal branching at the output of the amplifier's first stage on two networks. The first network is the analog delay line and differential AC amplifier. The second network is the circuit for stimulation artefact detection. The purpose of the analog delay line is to delay the signal from the output of the first stage, so that the circuit for stimulus artefact detection can detect it and adapt the characteristics of the amplifier by controlling bilateral switches $\mathrm{U}_{7}$ and $\mathrm{U}_{8}$ before it appears at the output stage. After that, the analog delay line signal is amplified in the output stage: $\mathrm{U}_{5}, \mathrm{U}_{6}, \mathrm{R}_{3}, \mathrm{R}_{4}, \mathrm{R}$ and $\mathrm{C}$.

Input protection of the amplifier is implemented by using resistor-diode network (not shown). This circuit prevents the damaging of input amplifiers caused by the presence of the large stimulation artefact. These protection elements will not prevent saturation of the instrumentation amplifier during stimulation artefact. Saturation recovery depends on the input amplifier's speed, so it can be very high, but the return of stabile isoelectric line will be very slow because of the very low cut-off frequency [20]. Stabilisation of the isoelectric line 
is implemented by connecting the integrators input to the ground instead to the output of the amplifier (Fig. 1) during stimulation artefact $\left(\mathrm{U}_{8}\right.$-on, and $\mathrm{U}_{7}$-off). In this way, the output voltage of the integrator is held at the value before the stimulation artefact. The Integrator will be turned on after the stimulation artefact. The Transfer function of the second stage (without presence of the stimulation artefact) is given by:

$$
A_{\mathrm{DII}}(s)=H(s) \cdot \frac{R_{4}}{R_{3}} \cdot \frac{s R C}{1+s R C},
$$

where $H(s)$ is the transfer function of the analog delay line. Low cut-off frequency of the amplifier is given by:

$$
f_{h}=\frac{1}{2 \pi R C}
$$

The circuit for stimulus artefact detection controls bilateral switches $\mathrm{U}_{7}$ and $\mathrm{U}_{8}$. This circuit consists of the $\mathrm{U}_{3}, \mathrm{U}_{4}, \mathrm{R}_{5}, \mathrm{R}_{6}, \mathrm{C}_{1}$, full-wave rectifier and monostable multivibrator. AC differential amplifier eliminates DC offset from the input stage. Low cut-off frequency of this amplifier is set above $10 \mathrm{kHz}$ because of the stimulation artefact fast recovery. With this high cut off frequency amplifier completely removes the EMG signal, and passes only the stimulation artefact. Adaptation of this amplifier to changes in DC component is very fast, because of the very high cut off frequency. This signal is then rectified using a full-wave rectifier. Rectification of stimulation artefact must be done because of different types of the stimulation pulses (monophasic, biphasic) [19]. The main purpose of this circuit is to turn-off the integrator in the feedback loop of the differential amplifier during stimulation artefact. Duration of the integrators turn-off time is increased by $1 \mathrm{~ms}$ with the monostabile multivibrator circuit because of accumulated charge from the discharging EMG electrodes.

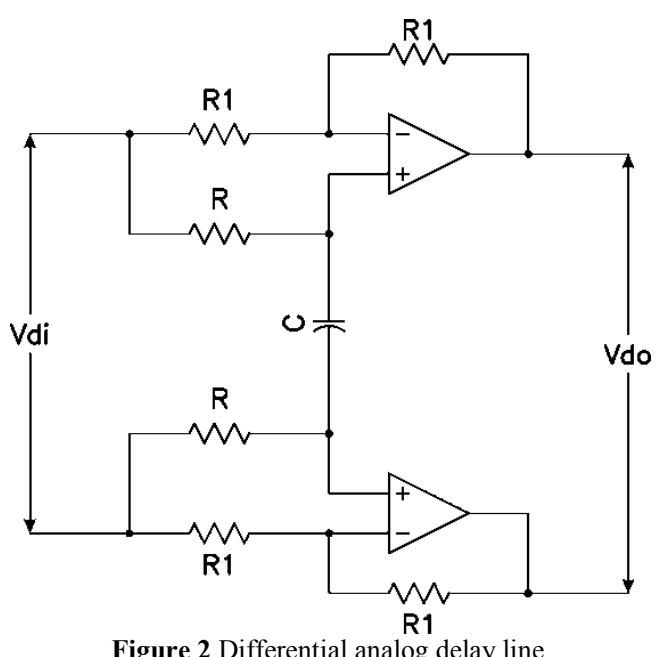

Analog delay line is implemented as differential allpass filter, which is shown in Fig. 2.

The transfer function of the proposed analog delay line is given by:
$H(s)=\frac{1-2 s R C}{1+2 s R C}$

By analysing Eq. (4), it can be shown that the amplitude characteristic is flat in the pass-band. Delay of the proposed circuit is given by:

$T=4 R C$.

Signal delay by using analog delay line is shown on the test signal in Fig. 3. The delay is set to $100 \mu \mathrm{s}$, for verification purposes.

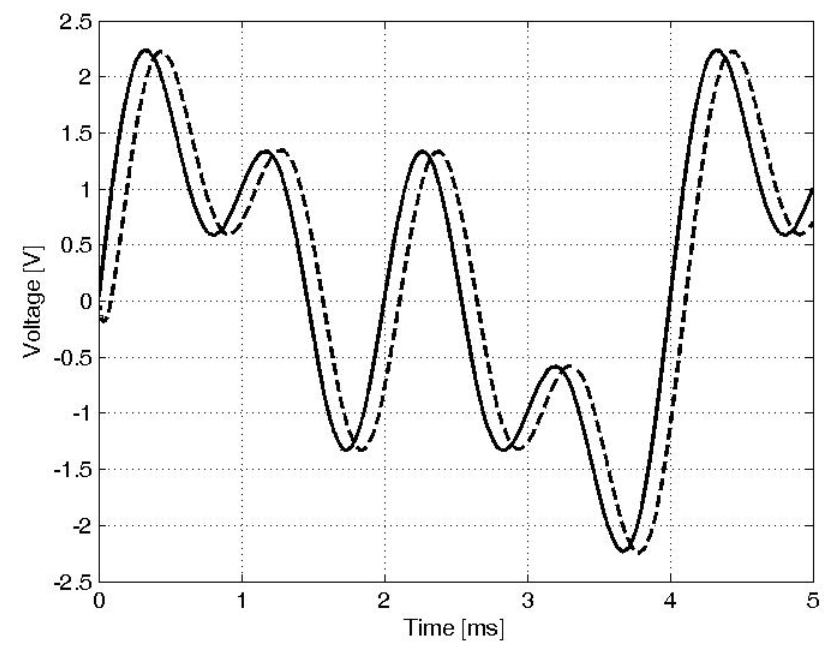

Figure 3 Differential analog delay line signals at the input (bold curve) and at the output (broken line)

The time delay for the proposed circuit is set to 22,4 $\mu \mathrm{s}$. This time is chosen because it is enough to adapt the characteristics of the integrator before stimulation artefact appears at the output stage.

\section{Circuit design of the novel fast recovery EMG amplifier}

The realized amplifier is shown in Fig. 4. Operational amplifiers $\mathrm{U}_{1}, \mathrm{U}_{2}$ and $\mathrm{U}_{5}$ with resistors $\mathrm{R}_{1}, \mathrm{R}_{2}, \mathrm{R}_{3}, \mathrm{R}_{10}$, $\mathrm{R}_{11}, \mathrm{R}_{12}$ and $\mathrm{R}_{13}$ form the standard instrumentation amplifier with three op-amps. This amplifier has the amplification of $60,82 \mathrm{~dB}$.

The analog delay line is placed between two stages of the instrumentation amplifier and is implemented by using $\mathrm{U}_{3}, \mathrm{U}_{4}, \mathrm{R}_{4}, \mathrm{R}_{5}, \mathrm{R}_{6}, \mathrm{R}_{7}, \mathrm{R}_{8}, \mathrm{R}_{9}$ and $\mathrm{C}_{1}$. For the given component values and from the Eq. (5), the time delay is set to $22,4 \mu \mathrm{s}$.

DC component suppression is implemented with integrator in the negative feedback loop of the differential amplifier by using $\mathrm{U}_{7}, \mathrm{R}_{16}, \mathrm{R}_{17}, \mathrm{R}_{18}$ and $\mathrm{C}_{2}$. Low cut-off frequency is set to $10 \mathrm{~Hz}$. The maximum $\mathrm{DC}$ signal value that can be suppressed is limited by the maximum output voltage of the integrator $V_{i(\max )}$ (defined by the powersupply voltage and op-amp output characteristics) and the attenuation of the resistive network $R_{16}, R_{17}$. The maximum DC suppression is given by:

$\left|V_{i n(D C)}\right|=\frac{\left|V_{i(\max )}\right|}{A_{I A}}\left(1+\frac{R_{16}}{R_{17}}\right)$. 
For high-precision detection of changes in the DC component, we introduced comparators $\left(\mathrm{U}_{15}\right.$ and $\left.\mathrm{U}_{16}\right)$. Their purpose was to detect saturation of the amplifier. Those comparators turn on bilateral switch $\mathrm{U}_{8 \mathrm{C}}$ which changes low cut-off frequency of the amplifier during saturation. Low cut-off frequency is changed to $100 \mathrm{kHz}$ during stimulation pulse. This method decreases adaptation of the amplifier to the changes of the DC signal at the input of the amplifier. Circuit for stimulation artefact detection is implemented by using a high-pass filter $\left(\mathrm{U}_{9}, \mathrm{U}_{10}, \mathrm{R}_{19}, \mathrm{R}_{20}, \mathrm{R}_{21}, \mathrm{R}_{22}, \mathrm{R}_{23}\right.$ and $\left.\mathrm{C}_{3}\right)$, a full-wave rectifier $\left(\mathrm{U}_{11}, \mathrm{U}_{12}, \mathrm{R}_{24}, \mathrm{R}_{25}, \mathrm{R}_{26}, \mathrm{R}_{27}, \mathrm{R}_{30}, \mathrm{D}_{1}\right.$ and $\left.\mathrm{D}_{2}\right)$ and $\mathrm{a}$ monostabile multivibrator U13:A.

To achieve high common mode rejection and patient protection according to the IEC606001-1 standard [21], we introduced a Driven Right Leg (DRL) circuit [20]. This circuit actively attenuates common mode signal in the first stage of the amplifier and limits the maximum current value that can flow through the patient to $1 \mu \mathrm{A}$ [21].

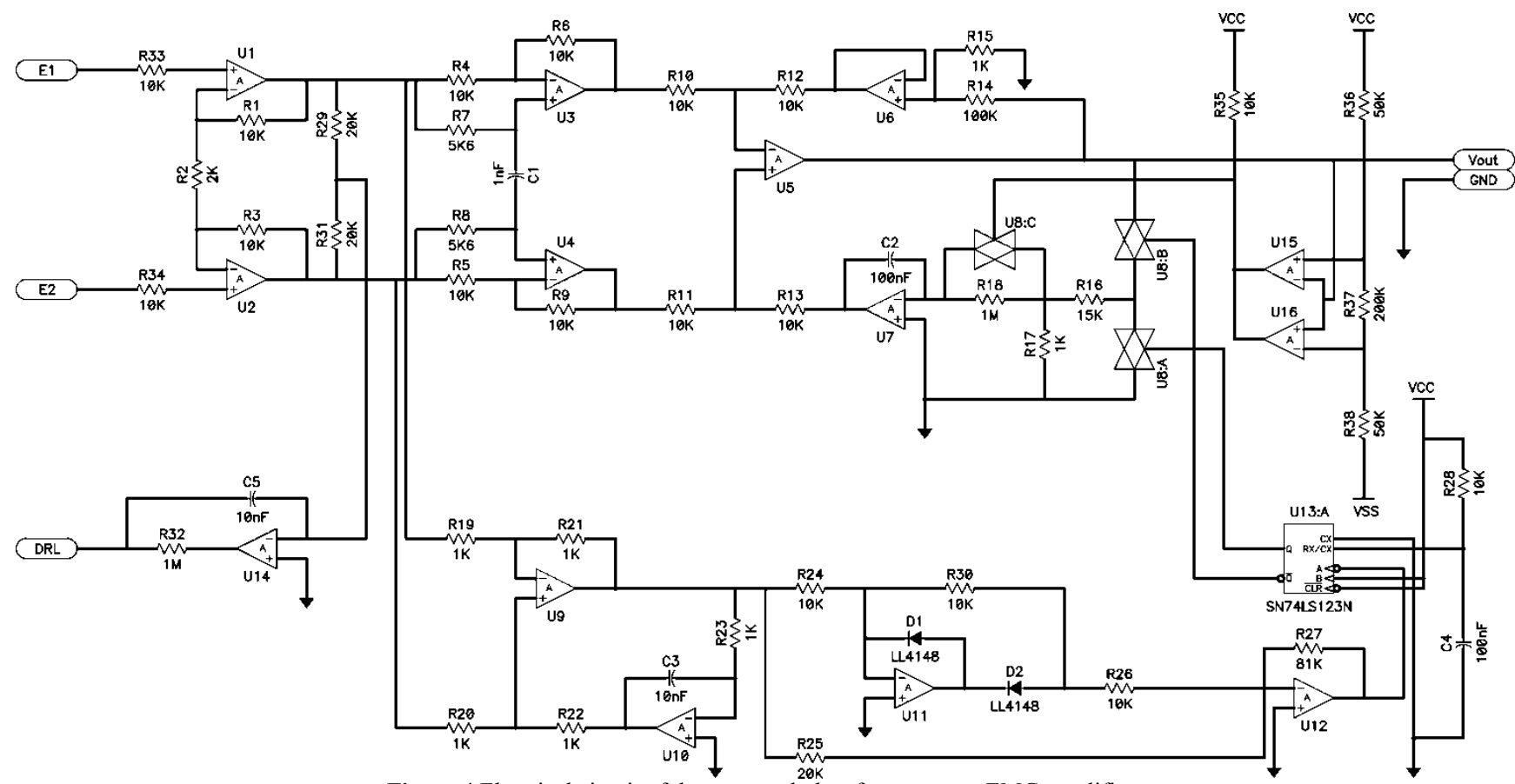

Figure 4 Electrical circuit of the proposed ultra-fast recovery EMG amplifier

\section{Simulation of the novel fast recovery EMG amplifier}

The circuit's stability and frequency analysis were performed using Matlab and Simulink. According to the schematic diagram in Fig. 4, three Simulink models were formed. The First model describes the transfer function for the differential mode signal of the whole amplifier (DM model) without stimulation artefact, the second model describes the transfer function for the differential mode signal during amplifiers adaptation to the changes of DC signal and the third model describes common mode signal for the first stage of the IA (CM model) and the third model. Bode frequency characteristics of the differential gain without presence of the stimulation artefact are presented in Fig. 5. Based on the Fig. 5, the differential gain equals $60,82 \mathrm{~dB}$ with a low cut-off frequency of $10 \mathrm{~Hz}$, and a high cut-off frequency of 100 $\mathrm{kHz}$.

Fig. 6 presents Bode plot during adaptation of the amplifiers characteristics to the changes of the input DC signal. This figure shows accelerated adaptation to the input DC component changes.

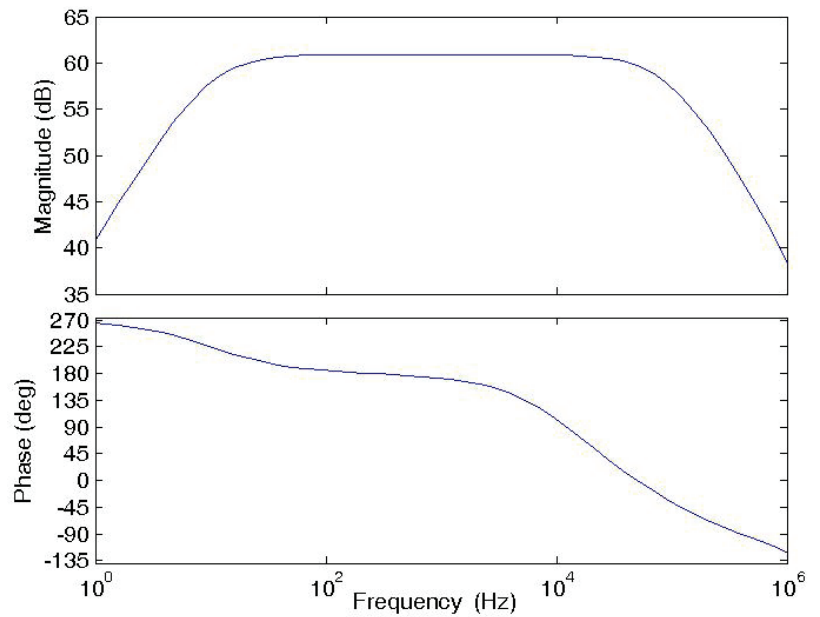

Figure 5 Bode frequency characteristics of differential gain without presence of the stimulation artifact

Fig. 7 shows the Bode frequency characteristics of the common mode gain. The CM model describes the common mode attenuation from the amplifier's input to the output for the first stage of the IA. The common mode signal attenuation at the output of the first stage is $30 \mathrm{~dB}$ at $50 \mathrm{~Hz}$. The open loop gain analysis shows that the system is stable with a gain margin of $23,9 \mathrm{~dB}$ and the phase margin of $75,5^{\circ}$. 


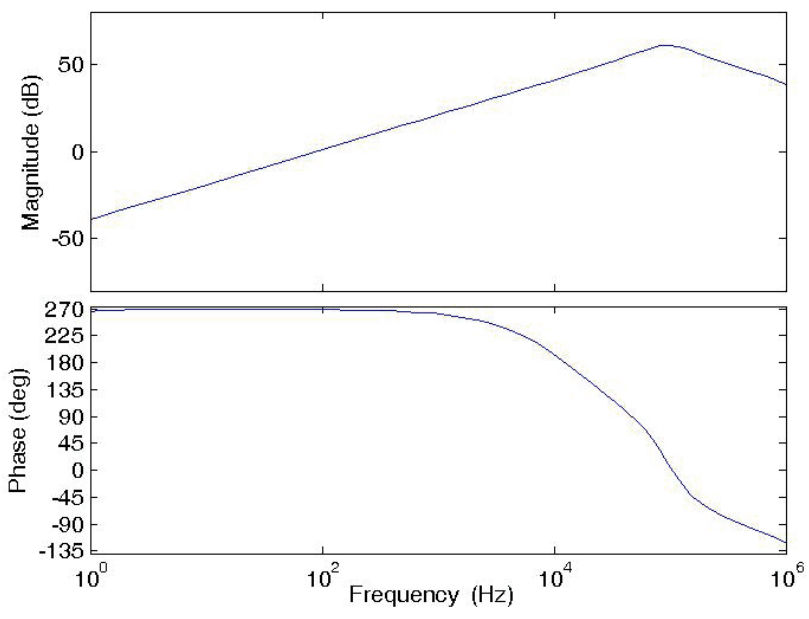

Figure 6 Bode frequency characteristics of differential gain during adaptation of the amplifiers characteristics

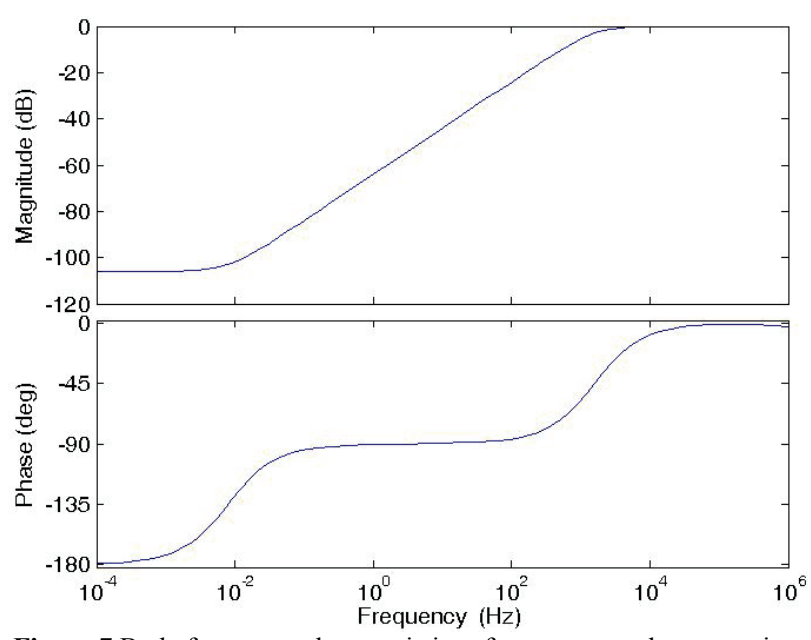

Figure 7 Bode frequency characteristics of common-mode attenuation in the first stage of the amplifier

\section{Testing of the novel fast recovery EMG amplifier}

The experimental verification of the proposed circuit using real signals is demonstrated by the EMG recording in an intentionally generated, extremely noisy environment. We recorded the EMG signal with and without presence of the stimulation pulses. EMG signals were recorded by using Arbo ECG-EMG electrodes H124SG positioned over the Flexor Digitorum m. The EMG signal of the three contractions of the Flexor Digitorum $\mathrm{m}$. is shown in Fig. 8. This figure represents raw EMG signal without the presence of the stimulation artefacts.

To verify amplifiers characteristics in the presence of the stimulation artifact, we used monophasic and biphasic stimulation pulses by the INTFES V1 electronic stimulator [22] and monophasic compensated pulse by the TremUNA stimulator [23].

Shown in Fig. 9 is amplifier's output during monophasic electrical stimulation. Stimulation parameters were set to the following values: stimulation current 10 $\mathrm{mA}$, stimulation pulse width $250 \mu \mathrm{s}$ and stimulation frequency is $30 \mathrm{~Hz}$. Figure shows that the proposed amplifier has ultra-fast recovery from the saturation and amplifies EMG signal between two stimulation pulses.

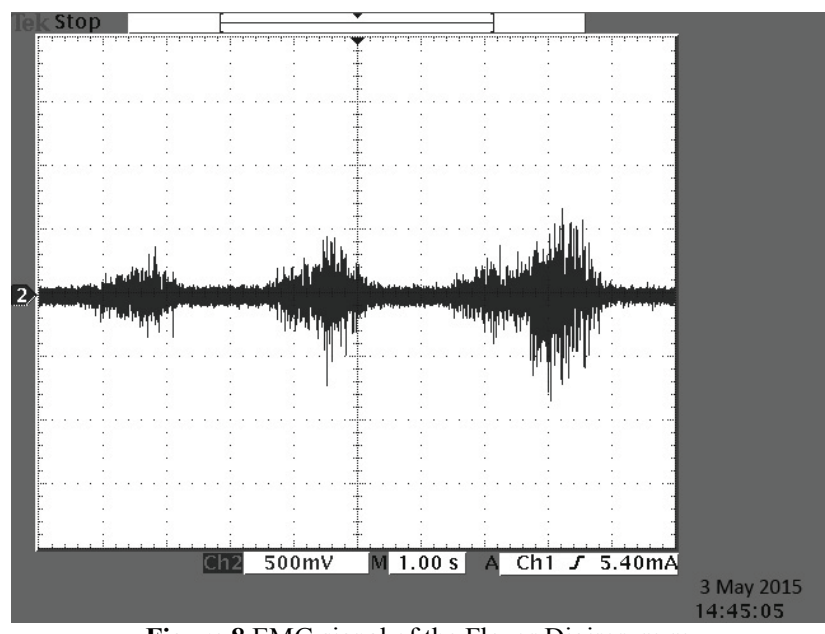

Figure 8 EMG signal of the Flexor Digirorum m

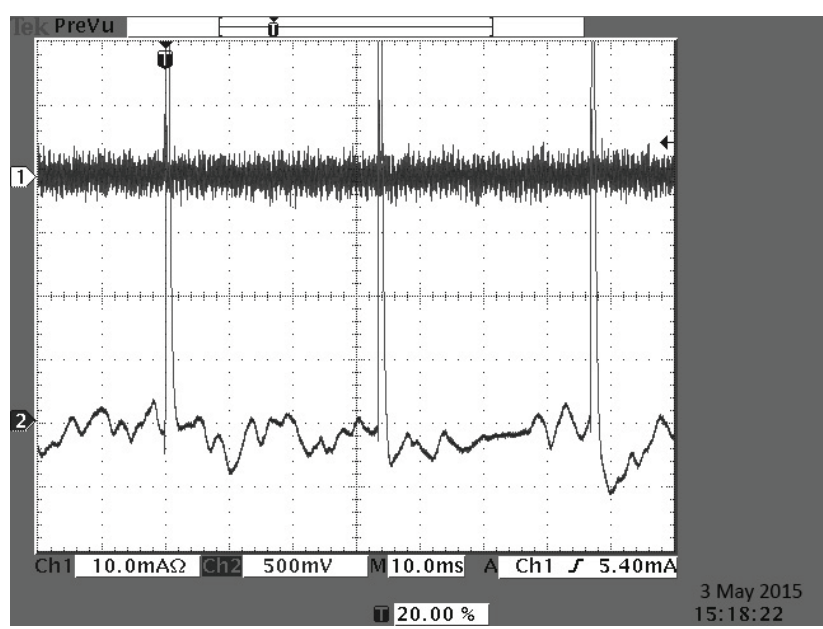

Figure 9 Output of the amplifier (Ch1) during monophasic electrical stimulation $(\mathrm{Ch} 2)$

Fig. 10 shows amplifier's output during biphasic stimulation. Stimulation parameters were set to: stimulation current $10 \mathrm{~mA}$, stimulation pulse width 250 $\mu$ s and stimulation frequency is $30 \mathrm{~Hz}$. Fig. 10 shows that the proposed amplifier has ultra-fast recovery from the saturation and amplifies EMG signal between two stimulation pulses.

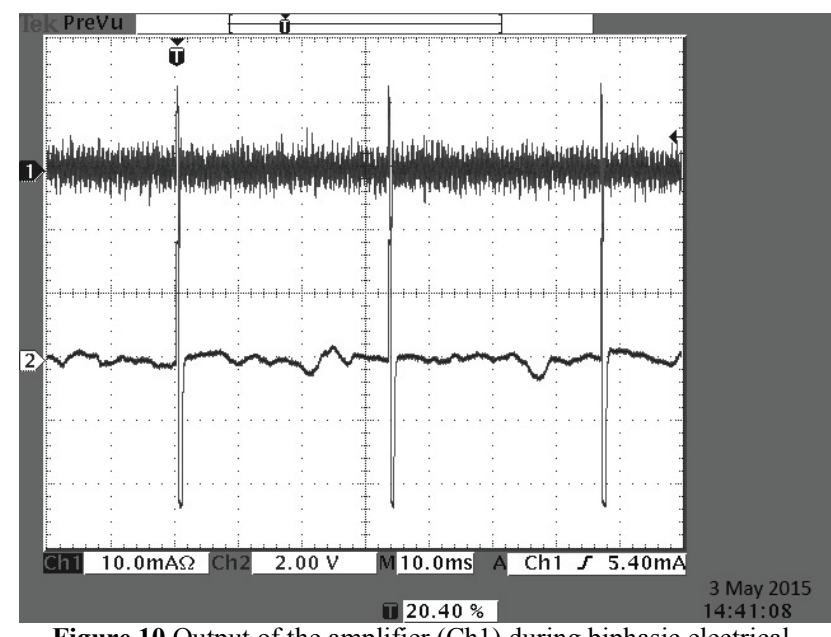

Figure 10 Output of the amplifier (Ch1) during biphasic electrical stimulation (Ch2)

Shown in Fig. 11 is amplifier's output during monophasic compensated stimulation. Stimulation 
parameters were set to: stimulation current $10 \mathrm{~mA}$, stimulation pulse width $250 \mu$ s and stimulation frequency is $20 \mathrm{~Hz}$. Fig. 11 shows that the proposed amplifier has ultra-fast recovery from the saturation and amplifies EMG signal between two stimulation pulses.

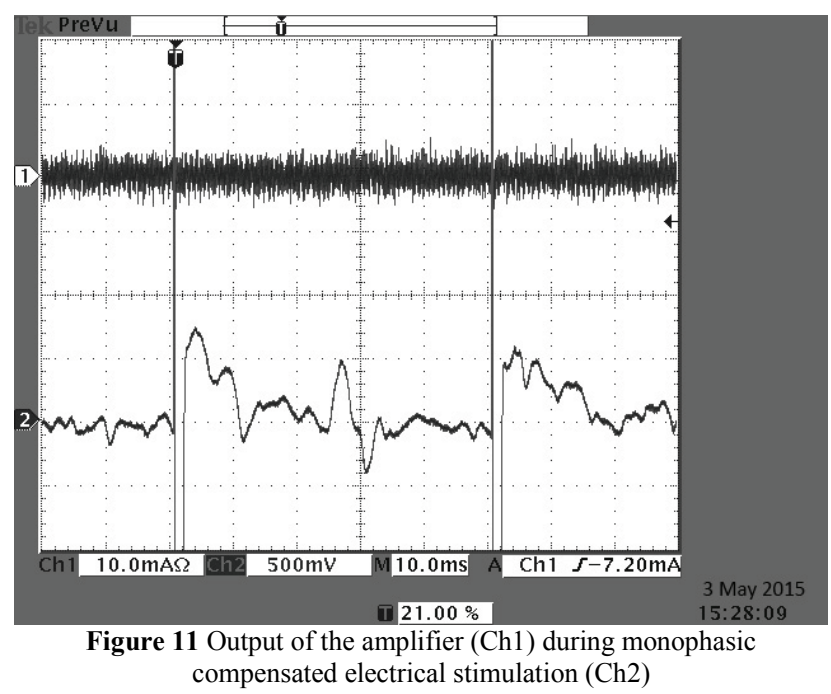

\section{Conclusion}

Proposed in this paper are design and development of the novel ultrafast recovery EMG amplifier for neural prosthesis control interface. Conventional EMG amplifiers have a serious problem of recovering from the stimulation artefacts. Thus they cannot be used for neural prosthesis applications.

It is shown that the proposed amplifier has novel architecture which enables its use in the neural prosthesis applications. The Standard three op-amp instrumentation amplifier with active DC suppression for use in EMG studies has been modified by introducing an analog delay line and circuit for stimulus artefact detection.

The analog delay line is placed between the first and the second stage of the instrumentation amplifier. By introducing the analog delay line, the signal from the input and the output of the amplifier is delayed, so the stimulus artefact detection circuit has enough time to change the characteristics of the active DC suppression circuit. This circuit also enables the detection of the stimulus artefact end, so the duration of the amplifiers adaptation can be increased for $1 \mathrm{~ms}$. This time interval is very important, for the accumulated charge in the recording electrodes can be discharged.

Fast recovery of the amplifier is achieved by changing low cut-off frequency of the active DC suppression circuit during stimulation artefact. During stimulation artefact, low cut-off frequency is increased from $10 \mathrm{~Hz}$ to $100 \mathrm{kHz}$, so the amplifiers adaptation time is drastically decreased.

The operation of the proposed circuits is described by equations presented in the paper. Frequency simulations verified the mathematical analysis and showed stability of the amplifier.

Experimental results show that the proposed amplifier can be used as a conventional EMG amplifier, or as a control interface of the neural prosthesis. It was also shown that the amplifier quickly recovers in the presence of the stimulation artefacts which come from different stimulator types. The Amplifier shows excellent performance during monophasic, biphasic and monophasic compensated stimulation pulses.

\section{Acknowledgements}

This research was supported by the Ministry of Education and Science of the Republic of Serbia (Project no. III-41007), and CEEPUS CIII-RO-0202 Network "Implementation and utilization of e-learning systems in study area of production engineering in Central European Region".

\section{References}

[1] Vodovnik, L.; Long, I. C.; Reswick, J. B.; Lippay, A.; Starbuck, D. Myo-Electric Control of Paralyzed Muscles. // IEEE Transactions on Biomedical Engineering. 12(1965), pp. 169-172. DOI: 10.1109/TBME.1965.4502374

[2] Popovic, D. B.; Sinkjær, T. External Control of Movement. // Springer. London, 2000. DOI: 10.1007/978-1-4471-0433-9_5

[3] Shalini, S.; Nikolic, S.; Popovic, D. An EMG-Controlled Grasping System for Tetraplegics. // Journal of Rehabilitation Research and Development. 32(1995), pp. 17-24.

[4] Knaflitz, M.; Merletti, R. Suppression of Simulation Artifacts from Myoelectric-Evoked Potential Recordings. // IEEE Transaction on Biomedical Engineering. 35(1988), pp. $758-763$. DOI: $10.1109 / 10.7278$

[5] Webster, J. G. Medical Instrumentation: Application and Design. // New York, Wiley, 1998.

[6] McGill, K. C.; Kenneth, L.; Cummins, L.; Dorfman, J.; Berlizot, B. B.; Luetkemeyer, K.; Nishimura, D. G.; Widrow, B. On the Nature and Elimination of Stimulus Artifact in Nerve Signals Evoked and Recorded Using Surface Electrodes. // IEEE Transactions on Biomedical Engineering. 29, 2(1982), pp. 129-137. DOI: 10.1109/TBME.1982.325019

[7] Van Rijn, M.; Peper, A. C.; Grimbergen, A. High-quality recording of bioelectric events. Part 1. Interference reduction, theory and practice. // Med. Biol. Eng. Comput. 28(1990), pp. 389-397. DOI: 10.1007/BF02441961

[8] Van Rijn, M.; Peper, A. C.; Grimbergen, A. High-quality recording of bioelectric events. Part 2. Low noise, lowpower multichannel amplifier design. // Med. Biol. Eng. Comput. 29(1991), pp. 433-440. DOI: 10.1007/BF02441666

[9] Van Rijn, M.; Peper, A. C.; Grimbergen, A. Amplifiers for bioelectric events: a design with a minimal number of parts. // Med. Biol. Eng. Comput. 32(1994), pp. 305-310. DOI: 10.1007/BF02512527

[10] Freeman, J. A. An Electronic Stimulus Artefact Suppresor. // Electroencephalography and Clinical Neurophysiology. 31, 2(1970), pp. 170-172. DOI: 10.1016/0013-4694(71)90188-X

[11] Babb, T. L.; Mariani, E.; Strain, G. M.; Lieb, J. P.; Soper, H. V.; Crandall, P. H. A Sample and Hold Amplifier System for Stimulus Artefact Suppresion. // Electroencephalography and Clinical Neurophysiology. 44, 4(1978), pp. 528-531. DOI: 10.1016/0013-4694(78)90038-X

[12] Walker, D. D.; Kimura, J. A Fast-Recovery Electrode Amplifier for Electrophysiology. // Electroencephalography and Clinical Neurophysiology. 45, 6(1978), pp. 789-702. DOI: 10.1016/0013-4694(78)90147-5

[13] Minzly, J.; Mizrahi, J.; Hakim, N.; Liberson, A. Stimulus Artefact Suppressor for EMG Recording during FES by a Constant-Current Stimulator. // Med. \& Biol. Eng. \& Comput. 31, 1(1993), pp. 72-75. DOI: 10.1007/BF02446897

[14] Nikolic, Z. M.; Popovic, D. B.; Stein, R. B.; Kenwell, Z. Instrumentation for ENG and EMG Recordings in FES 
Systems. // IEEE Trans. on Biomedical Engineering. 41, 7(1994), pp. 703-703. DOI: 10.1109/10.301739

[15] Thorsen, R. An Artefact Suppressing Fast-Recovery Myoelectric Amplifier. // IEEE Trans. On Biomedical Engineering. 46, 6(1999), pp. 764-766. DOl: 10.1109/10.764955

[16] De Michele, G. A.; Troyk, P. R. Stimulus-Resistant Neural Recording Amplifier. // Proc. Of the 25 annual International Conference of the IEEE EMBS, Mexico. 4, (2003), p.p. 3329-3332. DOI: 10.1109//EMBS.2003.1280857

[17] Shalaby, R.; Schauer, T.; Liedecke, W.; Raisch, J. Amplifier design for EMG recording from stimulation electrodes during functional electrical stimulation leg cycling ergometry. // Biomed Tech. 56, 1(2011), pp. 23-33. DOI: 10.1515/BMT.2010.055

[18] Hua, Y.; Lovely, D. F.; Doraiswami, R. Factors Affecting the Stimulus Artefact Tail in Surface-Recorded Somatosensory-Evoked Potentials. // Med Biol End Comput. 44, 3(2006), pp. 226-241. DOI: 10.1007/s11517-0060034-4

[19] Broderick, B. J.; Breen, P. P.; Laighin, G. O. Electronic Stimulators for Surface Neural Prosthesis. // Journal of automatic control. 18, 2(2008), pp. 25-33. DOI: 10.2298/JAC0802025B

[20] Winter, B.; Webster, J. Driven Right Leg Circuit Design. IEEE Transactions on Biomedical Engineering. 30, 1(1983), pp. 62-66. DOI: 10.1109/TBME.1983.325168

[21] International standard IEC60601-1. Medical electrical equipment. Sec. edition, IEC, 2000.

[22] Malesevic, N. M.; Popovicm-Maneski, L.; Ilic, V.; Jorgovanovic, N.; Bijelic, G.; Keller, T.; Popovic, D. B. A multi-pad electrode based functional electrical stimulation system for restoration of grasp. // Journal of Neuroengineering and Rehabilitation. 9, 66(2012). DOI: 10.1186/1743-0003-9-66

[23] Popovic-Maneski, L.; Jorgovanovic, N.; Ilic, V.; Dosen, S.; Keller, T.; Popovic, M. B.; Popovic, D. B. Electrical stimulation for the suppression of pathological tremor. // Med Biol Eng Computing. 49, 10(2011), pp. 1187-1193. DOI: $10.1007 / s 11517-011-0803-6$

\author{
Authors' addresses \\ Dr Vojin Ilić, Assistant Professor \\ Faculty of Technical Sciences, \\ Trg Dositeja Obradovića 6, \\ 21000 Novi Sad, Serbia \\ E-mail: vojin@uns.ac.rs
}

Dr Nikola Jorgovanović, Full Professor

Faculty of Technical Sciences,

Trg Dositeja Obradovića 6,

21000 Novi Sad, Serbia

E-mail: vojin@uns.ac.rs

Dr Aco Antić, Assistant Professor

Faculty of Technical Sciences,

Trg Dositeja Obradovića 6,

21000 Novi Sad, Serbia

E-mail: antica@uns.ac.rs

Dr Slobodan Morača, Assistant Professor

Faculty of Technical Sciences,

Trg Dositeja Obradovića 6,

21000 Novi Sad, Serbia

E-mail: moraca@uns.ac.rs

Dr Nikolae Ungureanu, Full Professor

Technical University of Cluj-Napoca,

Dr. V. Babes 62/A,

430083 Baia Mare, Romania

E-mail: unicu@ubm.ro 